Alkış Küçükaydın, M. ve İşcan, A. (2017). İlköğretim 3.Sınıf Türkçe ders kitapları ve öğretmen kılavuz kitabının yapılandırmacı öğrenme yaklaşımına uygunluk düzeyi. Ana Dili Eğitimi Dergisi, 5(1), 1-13.

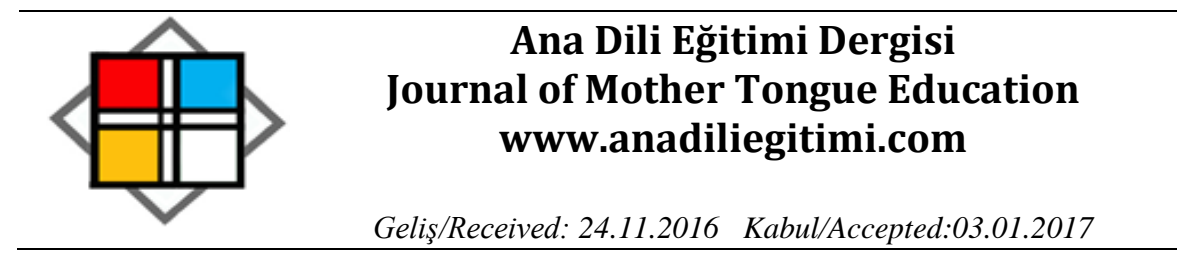

\title{
Illköğretim 3.Sınıf Türkçe Ders Kitapları ve Öğretmen Kılavuz Kitabının Yapılandırmacı Öğrenme Yaklaşımına Uygunluk Düzeyi*
}

\begin{abstract}
Menşure ALKIŞ KÜÇÜKAYDIN**
Adem işCAN***

Öz

Ders kitaplarının önemi, gelişen ve değişen teknolojik imkânlarla orantılı olarak artmaktadır. Bilimsellik ve benimsemiş olduğu temel yaklaşımı yansıtması açısından ders kitaplarının incelenmesi bir zorunluluk teşkil etmektedir. Benimsemiş olduğu yaklaşımı yansıtmayan ders kitaplarının yaklaşımın yanlış aktarılmasında etkisi olabilir. Bu çalışmada da ilköğretim düzeyindeki okullarda okutulmakta olan Türkçe ders kitaplarının yapılandırmacı öğrenme anlayışına uygunluk düzeyi incelenmeye çalışılmıştır. Üçlü setler halinde dağıtılan Türkçe ders kitabı, çalışma kitabı ve öğretmen kılavuz kitabı araştırma evreninde yer alan yayınevleri arasından random bir şekilde belirlenerek, geliştirilen ölçütler doğrultusunda tarama modeli yoluyla incelenmiştir. Elde edilen bulgulara göre set halinde incelenen ders kitaplarında birtakım eksikliklerin olduğu ve yapılandırmacı yaklaşımı tam olarak yansıtmadı̆̆ı, buna göre Türkçe ders kitabının metin görsel uyumu açısından yetersiz olduğu, tema içeriklerinin farklı boyutları içermediği, öğrenci çalışma kitaplarında görsel okuma ve görsel sunu alanında yetersiz etkinliklerin olduğu ve farklı etkinliklere yer verilmediği görülmüştür. Öğretmen kılavuz kitaplarının ise araştırmaya sevk edici nitelikte olmadı̆̆ı, ölçme değerlendirmede yeterli olmadığı, yönergeler sunmada başarısız olduğu ve yöntem teknikler konusunda hatalarının olduğu sonucuna ulaşılmıştır. Bulgulardan yola çıkılarak; ders kitabı inceleme kriterleri arasında "yapılandırmacı yaklaşıma uygunluk düzeyi" biçiminde madde eklenmesinin ilgili birimlerce dikkate alınması şeklinde önerilerde bulunulmuştur.
\end{abstract}

Anahtar Kelimeler: Yapılandırmacı öğrenme anlayışı, ilköğretim, ders kitabı

\section{Suitability of $3^{\text {rd }}$ Grade Primary School Turkish Textbooks and Teacher's Book to the Constructivist Learning Approach}

\begin{abstract}
The importance of course books has been increasing in proportion to developing and improving technological capabilities. In order to assess the scientificity and the main approach that course books have adopted, it is necessary to analyze them. Course books which do not reflect the approach they have adopted may have an influence on the misinterpretation of that approach. In this study, the congruence level of primary school Turkish course books with the constructivist learning approach is examined. In this study, Turkish course books printed by publishing companies and distributed in sets of three as course book, workbook, and teacher's book were randomly chosen from among those that were available and were examined using the criteria developed through the survey method. Based on the analysis, it was found that in the examined sets of course books, there were some deficiencies and the books did not accurately reflect the constructivist

\footnotetext{
* Bu çalışma birinci yazarın yüksek lisans tezinden üretilmiştir.

** Amasya Üniversitesi İlköğretim Sınıf Öğretmenliği ABD Doktora Öğrencisi-mensurealkis@hotmail.com

*** Doç. Dr. Gaziosmanpaşa Üniversitesi Eğitim Fakültesi Türkçe Eğitimi ABD-adem.iscan@gop.edu.tr
} 
approach, that the course books were inadequate in terms of visual support, theme contents in them did not reflect different dimensions, and that workbooks consisted of activities inadequate in terms of visual reading and visual presentation and did not include different activities. As for teacher's books, it was concluded that the books did not encourage research, were inadequate in terms of assessment and evaluation, were unsuccessful at giving instructions and consisted of mistakes in terms of methods and techniques. In the light of these findings, suggestions were made including the adding of an item like "congruence with the constructivist learning approach" among the criteria used in course books analysis.

Key Words: The Constructivist learning approach, primary education, course book

\section{Giriş}

Ülkeler benimsemiş oldukları eğitim politikalarını, yetiştirecekleri nesillere kitaplar aracılığıyla aktarabilir. Aktarılmak istenen bu eğitim politikaları ise elbette sadece kitaplar yoluyla gerçekleştirilemez ancak kitapların bu konudaki yardımcı işlevlerinin büyüklüğü de yadsınamaz. Eğitim programlarının yansıması konumundaki ders kitapları kimi zaman öğretim programlarının bir aynası ve görünen yüzü olarak tarif edilirken (Arslan ve Özpınar, 2009: 27), kimi zaman eğitim öğretimin gizli kahramanı olarak (Yapıcı,2004:122) kimi zaman da program ile öğrenci arasında köprü kuran temel materyal olarak görülmüştür (Küçükahmet, 2004: 13-14, Akt. Coşkun, 2008). Dolayısıyla ders kitaplarının hem içerik açısından hem de benimsemiş oldukları felsefe açısından birtakım sorumlulukları üstlendiğini söylemek mümkündür. Bununla beraber "ana dili eğitiminde ders kitaplarının oldukça önemli bir yeri vardır. Türkçenin eğitim ve öğretiminde programlarla birlikte ders kitaplarında kullanılan metinlerin dili, metinlerde yer alan kültürel ögeler oldukça önemlidir" (Ekmekçi ve Karadüz, 2015: 365). Bu nedenle yapı ve içerik açısından incelenen bir ders kitabının sorumlu olduğu felsefe, dil ve kültürel yapılarına da dikkat edilmelidir. Çünkü kitaplar, okuma yazmaya hazırlık becerilerini desteklemekte, çocukların dil gelişimlerini de etkilemektedir (Işıtan, 2016).

Hızla değişen teknoloji, bilimdeki yenilikler ve bu yeniliklerin eğitim üzerindeki yansımaları; yenileşmenin kendisini, reform denecek türden atılımlar yapmaya itmiştir. Ülkemiz de bu değişim ve yenilikleri takip ederek başta gelişmiş ülkeler olmak üzere dünyada kırktan fazla ülkenin eğitim sisteminde uygulanan yapılandırıcı yaklaşımı benimsemiştir (Güneş, 2009). Millî Eğitim Bakanlığı (MEB) tarafından 2003 ve 2004 yıllarında ilköğretim ders programları yapılandırmacı eğitim anlayışına göre geliştirilmiş ve 2005 yılından itibaren uygulanmaya başlanmıştır (Güven, 2010). 2015 yılında değiştirilen programla beraber, değişimlerin 2016-2017 eğitim öğretim yılından itibaren kademeli olarak değişeceği bildirilmiştir (URL-1). Yeni programla beraber ilköğretim Türkçe ders programında da birtakım değişiklikler olmuştur. Buna göre yeni Türkçe programında dinleme, okuma, konuşma, yazma becerilerinden başka görsel okuma ve görsel sunu öğrenme alanlarına yer verilmiştir. Öğrencilere kazandırılması istenen beceriler kazanımlar hâlinde sarmal bir yapıda, etkinliklere ağırlık verilerek ve süreç temelli ölçme değerlendirme anlayışılla hazırlanmıştır (Epçaçan ve Okçu, 2010). 
İlköğretim 3.Sınıf Türkçe Ders Kitapları ve Öğretmen Kılavuz Kitabının Yapılandırmacı Öğrenme Yaklaşımına Uygunluk Düzeyi

Değişen programla beraber kitaplar üçlü setler hâlinde dağıtılmaya başlanmıştır. Bunlar:

a) Ders Kitabı, b) Öğrenci Çalışma Kitabı, c) Öğretmen Kılavuz Kitabı biçiminde olmuştur. Türkçe ders programına bakıldığında içeriklerine göre; ders kitaplarında sadece metinler ve metinleri destekleyen görsel unsurlara yer verilmiş olup bu metinler öğrencilerin hayal gücünü geliştirmesi ve evrensel değerleri aşılaması bakımından önemli görülmüştür. Öğrenci çalışma kitaplarında bu metinleri destekleyen etkinlikler ve alıştırmalara; öğretmen kılavuz kitabında ise yönlendirmeler, formlar, ek etkinlik ve sorulara yer verilmiştir. Verilen bu yönlendirmeler planlama kısmında öğretmenlere yardımcı olmaktadır (Durukan, 2008; Kırcı, 2011). Ancak Epçaçan ve Okçu (2010)'nun öğretmen görüşlerine göre Türkçe ders kitaplarını incelemiş olduğu çalışma sonucuna göre öğretmenler ders kitaplarının yetersiz olduğunu düşünmektedir. Akkocaoğlu (2009) ise 5.sınıf Türkçe ders kitaplarını yapılandırmacı öğrenme anlayışına göre incelemiş ve incelenen kitapların üst düzey düşünme becerileri yönünden eksik, aynı zamanda süreç temelli ve temel yaşam becerilerine dönük değerlendirme sürecine yönelik etkinliklerin kısır olduğu sonucuna ulaşmıştır. Türkçe kitaplarını öğretmen görüşlerine göre inceleyen Şahin (2010) ise çalışma kitaplarında harita, kroki, plan, fotoğraf, resim vb. materyal ve kaynaklara yeteri kadar yer verilmediğine değinmiştir. Ayrıca tema sonlarında yer alan değerlendirme etkinliklerinin genellikle klasik yöntemlere uygun olduğu, yapılandırmacı anlayışı çok fazla yansıtmadığı sonucuna ulaşıımıştır. Sert (2012)'in yapmış olduğu çalışma sonucunda da öğrenci çalışma kitaplarının farklı bakış açısı geliştirme bakımından yetersiz olduğu görülmüştür.

\section{Kuramsal Çerçeve}

Şimşek (2004: 133) “...Ingilizce constructivism sözcüğünün Türkçe literatüründe yapıcılık, yapılandırmacılık, oluşturmacılık, gelişimcilik, yapısalcılık, çatkıcılık, bütünleştiricilik..." gibi farklı karşııklara gelebileceğini açıklamıştır. Aslan (2007: 46) yapılandırmacılık kavramını "öğrenme kuramı bakımından insanların nasıl öğrendiğini açıklamaya çalışan bir yaklaşımın adı, felsefi bakımdan ise bilgi bilim (epistomoloji) ile ilgili bir kavram" şeklinde hem kuram boyutuyla hem de felsefi açıdan açıklamıştır. Yaşar ise (1998) yapılandırmacılığın bir öğrenme öğretme stratejisi olmadığını, öğretme değil öğrenme üzerine odaklı olduğunu, bireyin daha önceden de bazı bilgilerle donanımlı olduğunu ifade etmiştir. Yaklaşımda tüm öğrenenler için tek bir hedef yazmak yerine, bireylerin ihtiyaçları doğrultusunda üst düzey becerilerini geliştirecek hedefler yazılır. Bunun için bireye anlamlı özgün görevler verilir, bilişsel çelişkiler sunulur. Bunlar yapılmadığında sürekli basit problemlerle uğraşan birey yaşamında karşılaşacağı problemlere çözüm üretemeyebilir (Yurdakul, 2008). Bunun yanında yapılandırmacılık; gözlem ve deney yoluyla elde edilecek pozitivist bilgi kazanımını da reddeder. Çünkü yapılandırmacılığın öncüsü kabul edilen Von Glasersfeld’e göre bilgi duyular veya iletişim aracılığıyla yani nesnel bir gerçeği keşifle değil ancak öznel deneyimlerle elde edilir (Yurdakul, 2004). Yapılandırmacılık bireye daha fazla sorumluluk yüklemekle beraber bilginin hem bireysel hem de sosyal ortamlarda kazanılacağını belirtmektedir. Buna göre yapılandırmacı bir öğrenme anlayışının 
yerleşebilmesi için öğrenme ortamlarının zenginleştirilmesi gereklidir. Çünkü bu yaklaşıma göre kesin bilgi olamayacağı gibi, bilgi de deneyimler yoluyla kazanılır (Gültekin, Karadağ ve Yılmaz, 2007). Yaklaşımla beraber okutulan ders kitaplarında da hem biçim ve içerik açısından hem de kuramsal açıdan değişikliklere gidilmiştir. Bu değişim yapılandırmacı yaklaşımın kendini göstermesiyle gerçekleşmiştir. Amankwa, Hammond ve Kofigah (2011)'e göre ders kitapları, toplumda var olan baskın değerlerin, inançların ve birtakım ideolojik mesajların öğrencilere aktarılması bakımından önemlidir. Ayrıca "nitelikli bir metin öncelikle bağdaşıklık ve tutarlılık açılarından iyi kurgulanmış olmalı" (Gündoğdu,2011:1226), bunun yanında yapılandırmacı anlayışa göre hazırlanan ders kitapları; öğrenenlerin belleğinde ortak bir alt yapı oluşturacak temel bilgilere yer vermeli, bu bilgileri ne kadar öğrendiklerini ölçme amacıyla yapılacak değerlendirmelerde açık uçlu ve düşünmeye sevk eden soruları kapsamalı, eleştirel ve yaratıcı düşünmeyi sağlayacak alt kategorilere yer vermelidir (Özatalay, 2007). Ders kitapları öğretmene öğretim konusunda yardımcı olduğu gibi öğrencilere de öğretmenlerin anlattıklarını istedikleri zaman ve tempoda tekrar etme olanağı verir (Küçükahmet, 2011).

\section{Araştırmanın Amacı}

Araştırmanın amacı, MEB Talim ve Terbiye Kurulu Başkanlığının 18.12.2009 tarih ve 303 sayıı yazısı ile basılmış bulunan İlköğretim 3. Sınıf Türkçe ders kitabı, öğrenci çalışma kitabı ve öğretmen kılavuz kitabının yapılandırmacı öğrenme anlayışına uygunluğunu inceleyip değerlendirmektir. Elde edilen bilgilere dayanılarak yeni hazırlanacak kitapların hazırlanmasına yönelik öneriler sunmak ve Türkçe ders kitabı, öğrenci çalışma kitabı ve öğretmen kılavuz kitabına yönelik katkı sağlamaktır. Bu doğrultuda aşağıda yer alan sorulara cevap aranmıştır.

1. İlköğretim 3.Sınıf Türkçe ders kitaplarının yapılandırmacı öğrenme yaklaşımına uygunluk düzeyi nedir?

2. İlköğretim 3.Sınıf Türkçe öğrenci çalışma kitaplarının yapılandırmacı öğrenme yaklaşımına uygunluk düzeyi nedir?

3. İlköğretim 3.Sınıf Türkçe öğretmen kılavuz kitaplarının yapılandırmacı öğrenme yaklaşımına uygunluk düzeyi nedir?

\section{Yöntem}

Bu araştırma ilköğretim 3. Sınıf Türkçe dersi ders kitabı, öğrenci çalışma kitabı ve öğretmen kılavuz kitabının yapılandırmacı öğrenme anlayışına uygunluğunu belirlemek amacıyla yapılmıştır. Araştırmada tarama modeli kullanılıışır. Tarama modeli; "bir konuya ya da olaya ilişkin katıımcıların görüşlerinin ya da ilgi, beceri, yetenek, tutum vb. özelliklerinin belirlendiği genellikle diğer araştırmalara göre görece daha büyük örneklemler üzerinde yapılan araştırmalara" denir (Büyüköztürk, Çakmak, Akgün, Karadeniz ve Demirel,2011: 231). Çok sayıda elemandan oluşan bir evrende, evren hakkında genel bir yargıya varma amacı güdüldüğünden ve evrenden seçilen bir 
İlköğretim 3.Sınıf Türkçe Ders Kitapları ve Öğretmen Kılavuz Kitabının Yapılandırmacı Öğrenme Yaklaşımına Uygunluk Düzeyi

örneklem üzerinde tarama yapıldığından genel tarama modeli kullanılmıştır. Çalışmada hangi sınıfın inceleme alanı içinde tutulacağı kolay örneklem tekniği kullanılarak belirlenmiştir.

\section{Evren ve Örneklem}

Araştırmanın evrenini, 2012-2013 eğitim-öğretim yılında ilköğretim 3. sınıflarda okutulması için Millî Eğitim Bakanlığı Talim ve Terbiye Kurulu Başkanlığı tarafından onaylanan Türkçe ders ve öğrenci çalışma kitabı ile öğretmen kılavuz kitapları oluşturmaktadır. Örneklemini ise; 2012-2013 eğitim öğretim yılında ilköğretim 3. sınıflarda okutulan, yayınevleri içerisinden random yoluyla belirlenen Türkçe ders ve öğrenci çalışma kitabı ile öğretmen kılavuz kitabı oluşturmaktadır.

\section{Veri Analizi}

Araştırmada; verilerin toplanması aşamasında doküman incelemesi ve literatür taraması yapılmıştır. Öncelikle dokümanlar incelenmiş, belgelerin analizi yapılmış, yapılandırmacılık ve ders kitabı inceleme alanlarında literatür taraması yapılmıştır. Elde edilen veriler fişleme tekniğiyle kaydedilmiştir. Ders kitabı, öğrenci çalışma kitabı ve öğretmen kılavuz kitabının incelenmesine yönelik olarak kriterler belirlenmiştir. Bu kriterleri belirleyebilmek için; "ilköğretim Programları ve Ders Kitaplarının Değerlendirilmesi Sonuçlarının Ortaöğretim ile Paylaşılması Çalıştayı Çalışma Raporları", “Türkiye ve Almanya'da İlköğretim Ders Kitapları Sempozyumu"ndan çıkan veriler, Konu Alanı Ders Kitabı İnceleme Kılavuzları, "MEB Ders Kitapları ve Eğitim Araçlarının İncelenmesi ve Değerlendirilmesine İlişkin Yönerge" ve MEB Talim ve Terbiye Kurulu Başkanlığının 14/03/2013 tarihli ders kitapları incelemesinde, değerlendirmeye esas alınacak kriterler incelenmiştir. Gerekli veriler toplandıktan sonra yapılandırmacı öğrenme anlayışına göre Türkçe ders kitabı, öğrenci çalışma kitabı ve öğretmen kılavuz kitabı değerlendirme kriterleri geliştirilmiştir. Geliştirilen kriter maddeleri, uzman görüşüne sunulmuş ve gerekli düzeltmeler yapılarak son şekline ulaşmıştır. İnceleme sonucunda elde edilen veriler değerlendirilerek ve uzman görüşleri alınarak her kitap için ayrı ayrı ölçütler takımı oluşturulmuştur. Türkçe Ders kitabı, öğrenci çalışma kitabı ve öğretmen kılavuz kitabı belirlenen kriterlere göre incelenirken yeterli ise "Uygun", var ama yeterli değil ise "Eksik", yetersiz ise "Uygun Değil" kısmında işaretleme yapılmıştır. Bunun sonucunda elde edilen verilerin değerlendirilmesi suretiyle sonuca ulaşılmış ve çeşitli öneriler geliştirilmiştir.

\section{Bulgular}

Yapılandırmacı Anlayışa Göre Hazırlanan Ölçütlerin Türkçe Ders Kitabı'nda Bulunması ile Illgili Bulgular

Serbest okuma metinlerinden biri olan "Gece" metninde şu ifadeler yer almaktadır:

“...Ben karanlıktan korkarım, dönelim.

-Korkma, ben önden gideyim. Sen beni izlersin.

Behram'ın içine kurt düştü: 
"Yani sen korkmuyor musun karanlıktan?

-Kesinlikle korkmam.

-Geceleri dam nasıldır?

-Çıkarsan kendin görürsün." (Alacalı ve Anaç,2012: 93). Metnin geçmiş olduğu bu sayfada yapılan resimlemede korkan, tereddüt eden bir çocuk resmi beklenirken, merdivene bir an önce çıkmaya hevesli bir çocuk izleniminin verildiği görülmektedir. Aynı metnin devamında ise "Hacıyolu" denen bir yıldız kümesinden bahsedilmekte ancak sayfada yer alan resimde uydu görseli yer almaktadır.

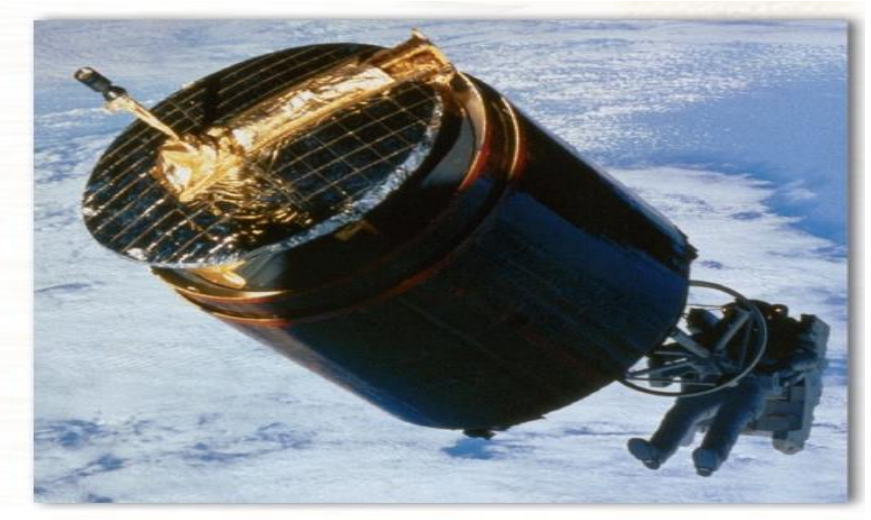

Resim 1.Yıldız Kümesinden Bahsedilen Resimleme

Resim 1'de verilen uydu görselinin sayfadaki metinle hiçbir ilgisi bulunmamaktadır. Ancak bir sonraki sayfada uydulardan bahsedilirken, metni açıklayıcı bir görsele yer verilmemiştir. Buna rağmen bu yaş döneminin hareketli olma özelliği göz önünde bulundurularak resim hareketliliğinin ihmal edilmediği de söylenebilir. Neredeyse tüm resimlerde bu hareketlilik söz konusudur.

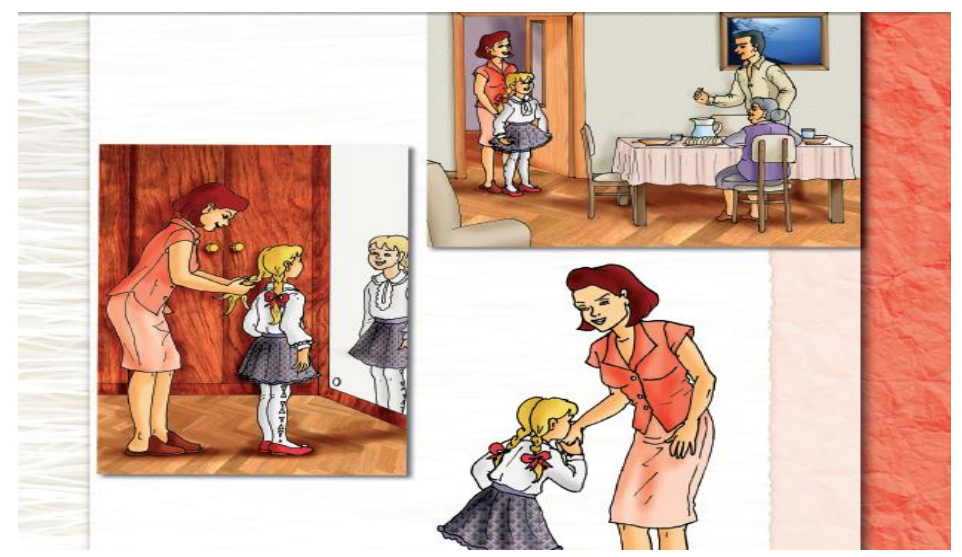

Resim 2.Resimlerdeki Hareketlilik

Incelenen ders kitabında yer alan metin ve şiirlerin belirlenen ölçütler doğrultusunda incelendiğinde dil becerileri açısından rahatsız edici bir durum olmadığı ve çocukları sosyal, zihinsel ve psikolojik yönden olumsuz etkileyecek herhangi bir ögeye rastlanmadığı söylenilebilir. Ancak "Atatürk" temasında sürekli aynı boyutların işlendiği, Atatürk'ün sanatçı kişiliğine, spora ve bilim insanlarına 
İlköğretim 3.Sınıf Türkçe Ders Kitapları ve Öğretmen Kılavuz Kitabının Yapılandırmacı Öğrenme Yaklaşımına Uygunluk Düzeyi

verdiği değere, müziğe, barışa ve eğitime olan ilgisine, çocuk sevgisine, kitap veya hayvan sevgisine vb. yer verilmediği saptanmıştır.

Yapılandırmacı Anlayışa Göre Hazırlanan Ölçütlerin Türkçe Dersi Öğrenci Çalışma Kitabı’nda Bulunması Ile ilgili Bulgular

Öğrenci çalışma kitabındaki etkinliklere bakıldığında; zihin ve kavram haritalarından, hikâye haritası ve balık kılçığına kadar pek çok yöntem ve tekniğin kullanıldığı ayrıca tahmine yönelik soruların, neden-sonuç ilişkisini sorgulayan, çıkarımlarda bulunulması beklenen, benzerlik ve farklılıkların neler olduğunu sorgulayan, empati kurduran ve özgün eserler çıkarılmasını isteyen sorulara da yer verildiği görülmektedir. Bu nedenle çalışma kitaplarında yer alan etkinliklerin temel becerileri (eleştirel düşünme, yaratıcı düşünme ve problem çözme) geliştirmeye yönelik hazırlanmasının yapılandırmacı anlayışa uygun olduğu söylenebilir. Bununla birlikte incelenen çalışma kitabında görsel okuma ve görsel sunu alanında dengesiz bir dağılımın olduğu da görülmüştür. Görsel okuma alanında; verilen resmi yorumlama, resim ve metin ilişkisi kurma, metinle ilgili resim yapma ve resimlerle ilgili metin yazma üzerinde odaklanılmış olup görsel okuma bir bakıma resim ve fotoğraf okumaya dönüştürülmüştür. Ayrıca beden dilini yorumlama, renkleri tanıma, tablo ve grafik oluşturma ile sunularında bilişim teknolojilerinden yararlanma etkinlikleri birer etkinlikle geçiştirilirken; harita ve kroki okuma, reklamlarda verilen mesajı anlayıp yorumlama, bilgi toplamak amacıyla bilişim teknolojilerinden yararlanma etkinliklerine yer verilmediği tespit edilmiştir. Bu nedenle incelenen çalışma kitabının bu ölçütü karşılamadığı görülmüştür.

Tema sonlarındaki değerlendirme çalışmalarının tamamı incelendiğinde, bir iki tema sonu değerlendirme çalışması dışında yapılandırmacı öğrenme anlayışına göre hazırlanmış çalışmalara daha az rastlanmıştır. Sadece bir tane $5 \mathrm{~N} 1 \mathrm{~K}$ etkinliği ve bir tane tablo ve grafik okuma yer alırken; balık kılçığı, harita ve kroki okuma, karikatürde verilen mesajı okuma, günlük, anı yazma, duyuru, afiş hazırlama, kısa oyunlar yazma gibi çalışmalara yer verilmemiştir. Buna rağmen hikâye haritası, nedensonuç ilişkisi, verilen metnin ana fikri ve şiirin ana duygusu ve konusu istenmektedir. İncelenen çalışma kitabının daha çok klasik yöntemlere göre hazırlandığı, yapılandırmacı anlayışın gerekli kıldığı değerlendirme çalışmalarının ise serpiştirildiği görülmüştür.

Öğrenci çalışma kitabında ayrıca zekâ türlerine uygun etkinliklere yer verildiği ancak müzikselritmik zekâya yönelik tek bir etkinliğin bulunmadığı görülmektedir. Bu nedenle çalışma kitapları bu ölçüte göre uygun ancak eksiktir. Ayrıca hiçbir etkinlikte altı şapkalı düşünme tekniğine, münazaraya, gerçek ve hayali çatışmalar çözmeye, düşün-tartış-yaz-paylaş çalışmalarına, eşli öğrenmeye, işbirliğine dayalı öğrenmeye yer verilmemiştir.

Yapılandırmacı Anlayışa Göre Hazırlanan Ölçütlerin Öğretmen Kılavuz Kitabı'nda Bulunması Ile ilgili Bulgular 
İncelenen öğretmen kılavuz kitabında (ÖKK) örnek bir problem durumunun sunulması, problemin çözümü, gerekli yerlerde hatırlatmaların yapılması, uyarma ve değerlendirme gibi basamaklara yer verilmediği görülmüştür. Verilen problem durumları yüzeysel olarak işlenmiş, çözümleri için öneriler sunulmamış, bununla beraber örnek problem durumu ve öneriler de gösterilmemiştir. Problem çözme becerisini geliştirmeye yönelik ancak bir iki ifade tespit edilmiştir. Bu ifadeler;

“Öğretmenlerinize mahalle ya da sokaklarda yaşanan çevre sorunlarını belirleyerek (örneğin; çöplerin zamanında toplanıp toplanmaması, sokakların temizliği, yeşil alanların olup olmadığını vb.) çözüm önerileriyle birlikte anlatmalarını söyleyiniz." (Öğretmen Kılavuz Kitabı:308), “Öğrencilerinize, 'Bir çocuk doktoru olduğunuzu düşünün. Çocuk dergilerinden birine, yemek seçen çocukları dengeli beslenmeye ikna edici ve bilgilendirici bir yazı yazmanız istendi. Neler yazardınız?' sorusunu sorarak düşünmelerini sağlayınız" (Öğretmen Kılavuz Kitabı: 296) şeklindedir.

Incelenen ÖKK'da Bloom Taksonomisi'nin tüm basamaklarına göre soruların dağılım gösterdiği görülebilir. Ayrıca ÖKK'da en çok kullanılan yöntemler; tartışma, rol oynama, anlatım, özetleme, oyun oynama ve gösteridir. Ancak bu yöntemlerin dışında yapılandırmacı yaklaşımın benimsemiş olduğu gözlem-inceleme ve problem çözmeye ilişkin hiçbir yönergeye rastlanmamıştır.

Incelenen ÖKK'da en çok kullanılan teknikler ise; beyin fırtınası, soru cevap, zihin haritası ve dramadır. Beyin fırtınası, drama ve soru cevap tekniklerinin oldukça güzel, yerinde ve tekniğe uygun kullanıldığı söylenebilir. Ancak kılavuz kitapta bu tekniklerin kullanım özelliklerine dair bilgilendirici not bulunmamaktadır. Bununla beraber zihin haritası zihinsel bir yapılandırmanın ötesinde sadece kelime çağrışımı için kullanılmıştır. Örneğin; "Atatürk'ün Yaşamı" metniyle bağlantılı olarak sadece Atatürk kelimesinin ne çağrıştırdığını yazmaları istenmiştir. Kelime çağrışımı yerine daha karmaşık ama anlaşılır, sembollerin ve farklı görsellerin kullanıldığı bir zihin haritası oluşturma yoluna gidilmemiş, kimi zaman zihin haritası ve kavram haritası birbirine karıştırılmıştır.

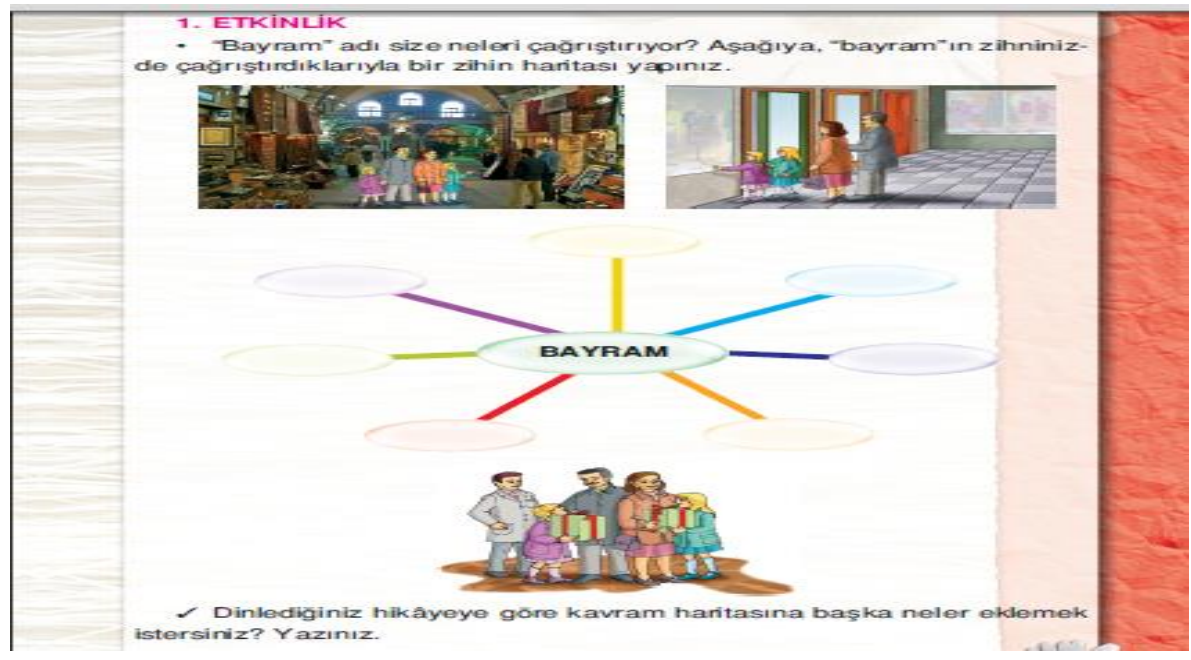

Resim 3. Zihin Haritası Kullanımı 
İlköğretim 3.Sınıf Türkçe Ders Kitapları ve Öğretmen Kılavuz Kitabının Yapılandırmacı Öğrenme Yaklaşımına Uygunluk Düzeyi

Resim 3'te öğrenenlerden ön bilgilerine dayanılarak bir zihin haritası oluşturmaları isteniyor. Ancak devamında ve kılavuz kitaptaki yönergede "Dinlediğiniz hikâyeye göre kavram haritasına başka ne eklemek istersiniz?" denilmektedir. Bunun dışında balık kılçığı tekniğine ait sadece bir yönerge tespit edilebilmiştir. Ayrıca ülkenin her bölgesinde aynı yöntem ve tekniğin yeterli olamayacağı göz önünde bulundurularak alternatif yöntem ve teknikler de sunulmamıştır.

Elde edilen bulgulara dayanarak genel olarak tüm öğrenme alanlarına eşit dağııım gösteren bir ölçme değerlendirme çalışmasının yapıldığı söylenebilir. Ancak “Öğrenci İzleme Form”larında görsel okuma ve görsel sunu öğrenme alanları verilmemiş, ölçme ve değerlendirme formlarının yönergelerde kullanılması gerektiği söylenmiş ve birtakım temalarda bu formlara yer verilmemiş, kavram haritası ile ilgili çelişkiler saptanmış olduğundan belirlenen ölçüte göre ÖKK'nın eksik olduğu görülmektedir. ÖKK'da yer alan ifadeler incelendiğinde sözlük, kılavuz vb. kullanmaya, bilişim teknolojilerini kullanmaya, gözlem ve görüşme yapmaya, gazete, kitap, ansiklopedi vb. yazılı kaynaklardan araştırma yapmaya yönelten ifadelere oldukça çok rastlanırken; harita okumaya yönelten sadece bir ifadeye rastlanmıştır. Bununla beraber anket kullanmaya, soru formları hazırlamaya, grafik veya kroki okumaya yönelten ifadelere de rastlanmamıştır. Üstelik Türkçe dersi kazanımları arasında "Grafik ve tablo ile verilenleri yorumlar, harita ve kroki okur" ifadeleri bulunmakta, ancak bu kazanımları gerçekleştirmeye yönelik ifadelere rastlanamamaktadır. Ayrıca incelenen ÖKK'da bilgi teknolojilerinin kullanımına yönelik yönergelerin bulunduğu ancak ÖKK'nın birincil kaynakları kullanmaya yönelten çalışmalarda yeteri kadar başarılı olamadığı, bu nedenle de ÖKK'nın belirlenen ölçüte göre eksik olduğu sonucuna ulaşılmıştır.

\section{Tartışma, Sonuç ve Öneriler}

Incelenen Türkçe ders kitabında yer alan şiir ve metinlerin öğrenenlerin farklı ilgi alanlarına sahip olduğu düşünülerek hazırlandığı ancak görsel ögelerde yetersizlikler ya da görselle metin arasında ilişki kurulamayan parçaların olduğu, metinlerin öğrenenlerin bilgilerini günlük hayata transferlerini kolaylaştırıcı nitelikte ve dil becerilerini geliştirme açısından uygun olduğu ancak aynı metinlerin yine görsel uyumu sağlayamama ve hayal dünyalarına hitap etme açısından eksik olduğu söylenebilir. Ayrıca metinlerin öğrenenlerin kendi öğrenmelerini yapılandırmaya katkı sağlayabileceği ve sosyal, zihinsel ve psikolojik gelişimlerini olumlu yönde etkileyeceği belirtilebilir. Gündoğdu (2011)'e göre; nitelikli bir metinde öncelikle bağdaşıklık ve tutarlıığın olması gerektir. Çünkü metinde verilmek istenen mesajın kolay algılanması ancak bağdaşıklık ve tutarlılık ile sağlanabilir. İncelenen Türkçe öğrenci çalışma kitabında yer alan etkinliklerin öğrenenlere temel becerileri kazandırmaya yönelik olarak hazırlandığı sonucuna ulaşılabilir. Yine etkinliklerin metinden yararlı bilgileri bulma, seçme, keşfetme, araştırma, metni genel olarak anlama, yorumlama, geliştirme ve düşünce oluşturma, metinde iç ve dış bağlantılar oluşturma, çıkarımlar yapma, sorgulama, sıralama, sınıflama, metinleri 
günlük yaşama aktarma gibi bilgilere yer verdiği, yazma ve dil bilgisi etkinliklerinin metnin konusuyla ilişkili, yazım kuralları ve noktalama işaretleriyle bağlantılı olarak yapılandırmacı anlayışa uygun olduğu sonucunun; dil bilgisi ile ilgili etkinliklerin kazanımlarla uyuşması bakımından Durukan (2008)'ın araştırmasıyla örtüştüğü söylenebilir. Etkinliklerin görsel okuma ve görsel sunuyu destekleyen ögelere yer vermesi konusunda sıkıntı olduğu ve yapılandırmacı anlayışa uygun olmadığı söylenebilir.

Incelenen ÖKK'da yer alan yönergelerin eleştirel düşünme ve yaratıcı düşünme becerilerini öğrenenlere kazandırması bakımından yeterli olduğu ancak problem çözme becerisini kazandırmada uygun olmadığı sonucuna ulaşılmıştır. Metin inceleme sorularının metni anlama, yapılandırma ve çözümlemeye, yer alan yöntem ve tekniklerin metnin türüne ve özelliğine uygun olduğu sonucuna ulaşılmıştır. Ancak bu yöntem ve tekniklerin kullanımında hatalar yapılmış ve teknikler birbirinin yerine kullanılmıştır. Ölçme ve değerlendirme çalışmaları yapılırken “Öğrenci İzleme Formları”nda görsel okuma ve görsel sunu öğrenme alanına yer verilmemiş ve bulgular kısmında belirtilen çelişkilere rastlanmıştır. Araştırma sonucunda elde edilen ÖKK'nın yöntem ve teknikler konusunda yetersiz ve ölçme değerlendirme çalışmaları açısından kısmen yeterli olması Erdoğan (2007)'ın çalışmasıyla örtüşmektedir. Ayrıca ÖKK'nın, temel becerilerin (eleştirel düşünme, yaratıcı düşünme ve problem çözme) kazandırılması açısından yetersiz ve kullanılan ölçme değerlendirme teknikleri bakımından kısır oluşu Akkocaoğlu (2009)'nun çalışmasıyla da örtüşmektedir. İşeri (2007)'ye göre yetersiz özelliklere sahip ders kitapları öğrenme ortamında kaynak veya kılavuz olma gibi özellikler yönünden işlevlerini yerine getiremezler. Genel anlamda çalışmadan elde edilen sonuçların literatürle (Erdoğan, 2007; Güven, 2010; Kılıç, 2008; Şahin, 2008) uyumlu olduğu görülmüştür.

Araştırma bulguları ve sonuçlarından hareket edilerek şu öneriler ileri sürülebilir:

$\checkmark \quad$ Türkçe Ders Kitaplarına konulacak metinlerin kendi içinde tutarlılık ve bütünlük sağlayıp sağlamadığına bakılarak metin görsel ilişkisi sorgulanabilir.

$\checkmark \quad$ Ders kitaplarına konulacak görsellerde resim ve fotoğraf dışında harita, kroki, levha vb. görsel içeriği fazla olan ayrıca sanat değeri taşıyan ve öğrenenlere sanatsal estetik becerisini kazandıracak ögelere yer verilmesi esası aranabilir.

$\checkmark \quad$ Özellikle "Atatürk" temasındaki metinler tekrar gözden geçirilerek Atatürk-çocuk, Atatürk-sanat, Atatürk-doğa vb. ilişkilerinin vurgulandığı metin seçimi yoluna gidilebilir.

$\checkmark \quad$ Türkçe Öğretmen Kılavuz Kitabı'nda özellikle problem çözme becerisini geliştirmeye yönelik etkinlik ve yönergelere yer verilebilir.

Öğretmene rehber olması açısından Öğretmen Kılavuz Kitaplarında yöntem ve teknikler tanıtılabilir ve örnekler sunulabilir.

Öğrenci Çalışma Kitaplarında daha çok karikatüre, diyagrama, tabloya, çizelgeye, şablona, levha ve plana yer verilebilir. 
İlköğretim 3.Sınıf Türkçe Ders Kitapları ve Öğretmen Kılavuz Kitabının Yapılandırmacı Öğrenme Yaklaşımına Uygunluk Düzeyi

Öğrenci Çalışma Kitaplarında etkinlik olarak anket doldurma, gezi gözlem yapma, görüşme formu doldurma ve soru formu hazırlama vb. kaynağın kendisine bizzat ulaşmayı sağlayan çalışmalara yer verilebilir.

Öğrenci Çalışma Kitaplarında öğrenenleri grup olarak iş birliğine teşvik eden etkinliklerin olmaması, sosyal yapılandırmacı anlayışın göz ardı edildiğini düşündürülebilir. Bu nedenle grup çalışmasını teşvik edecek (beraber şiir yazıp besteleme gibi) çalışmalara yer verilebilir.

$\checkmark \quad$ MEB Talim ve Terbiye Kurulu Başkanlığınca belirlenen ve okutulacak ders kitaplarının incelenme ve değerlendirilmesinde esas olacak kriterlere "yapılandırmacı yaklaşıma uygunluk" şeklinde ek bir kriter konulabilir.

\section{Kaynaklar}

Akkocaoğlu, N. (2009). MEB ilköğretim 5.sınıf Türkçe dersi öğrenci çalışma kitabı ve öğretmen kılavuz kitabının yapılandırmacı öğrenme yaklaşımına uygunluğunun incelenmesi. Yayımlanmamış Yüksek Lisans Tezi, Hacettepe Üniversitesi Sosyal Bilimler Enstitüsü, Ankara.

Alacalı, O. ve Anaç, G. (2012). ilköğretim Türkçe 3.sınıf ders kitabı ve öğrenci çalışma kitabı. İstanbul: Dörtel Yayıncllık.

Amankwa, K.O, Hammand, A.B. ve Kofigah, F.E. (2011). What is in a texbook? Investigating the language and literacy learning princioles of the "gateway to english" texbook series, pedogogy. Culture and Society, 19(2), 291-310.

Arslan, M. (2007). Eğitimde yapılandırmacı yaklaşımlar. Ankara Üniversitesi Eğitim Bilimleri Fakültesi Dergisi, 40(1), 41-61.

Arslan, S. ve Özpınar, i. (2009). Yeni ilköğretim 6. sınıf matematik ders kitaplarının öğretim programına uygunluğunun incelenmesi. Çukurova Üniversitesi Eğitim Fakültesi Dergisi, 3(36),26-38.

Büyüköztürk, Ş., Çakmak, E.B., Akgün, Ö.E, Karadeniz, Ş. ve Demirel, F. (2011). Bilimsel Araştırma Yöntemleri. Ankara: Pegem Akademi.

Coşkun, B. (2008). Ilköğretim 5.sınıf Türkçe dersi öğrenci çalışma kitaplarının öğretmen görüşlerine göre değerlendirilmesi. Yayımlanmamış Yüksek Lisans Tezi, Çukurova Üniversitesi Sosyal Bilimler Enstitüsü, Adana.

Durukan, E. (2008). Türkçe dersi öğretim programının (6-8.sınıflar) hedef ve kazanımları doğrultusunda 7.sınıf Türkçe dersi öğrenci çalışma ve öğretmen kılavuz kitaplarının değerlendirilmesi. Yayımlanmamış Yüksek Lisans Tezi Karadeniz Teknik Üniversitesi Sosyal Bilimler Enstitüsü, Trabzon.

Ekmekçi, V. ve Karadüz, A. (2015). Yurt dışında yaşayan iki dilli çocuklar için hazırlanan Türkçe ve Türk kültürü ders kitabına eleştirel bir bakış. Turkish Studies, 10(15), 361-378

Epçaçan, C. ve Okçu, V. (2010). İlköğretim Türkçe ders kitaplarının öğretmen görüşleri doğrultusunda değerlendirilmesi. Millî Eğitim, 187, 39-51. 
Erdoğan, T. (2007). Illköğretim 3.sınıf Türkçe dersi öğretmen kılavuz kitabı ve öğrenci çalışma kitabının yapılandırmacı yaklaşıma uygunluğu. Mehmet Akif Ersoy Üniversitesi Eğitim Fakültesi Dergisi, 8(14), 163172.

Gültekin, M., Karadağ, R. ve Yılmaz, F. (2007). Yapılandırmacılık ve öğretim uygulamalarına yansımaları. Anadolu Üniversitesi Sosyal Bilimler Dergisi, 7(2), 503-528.

Gündoğdu, A.E. (2011). Illköğretim sekizinci sınıf dinleme metinlerinin çeşitli değişkenler açısından incelenmesi. Turkish Studies, 6(1), 1217-1227.

Güneş, F. (2009). Türkçe öğretiminde günümüz gelişmeleri ve yapılandırıcı yaklaşım. Mustafa Kemal Üniversitesi Sosyal Bilimler Enstitüsü Dergisi, 6(11),1-21.

Güven, S. (2010). İlköğretim hayat bilgisi dersi ders ve öğrenci çalışma kitaplarının öğretmen görüşlerine göre değerlendirilmesi. Eğitim ve Bilim, 35(156), 84-95.

Işıtan, S. (2016). Özel amaçla yazılmış çocuk kitapları. Turkish Studies, 11(4), 471-492.

İşeri, K. (2007). Altıncı sınıf Türkçe ders kitabının ilköğretim Türkçe programının amaçlarına uygunluğunun değerlendirilmesi. Dil Dergisi, 136, 58-74.

Kılıç, H.C. (2008). İlköğretim sınıf öğretmenlerinin matematik ders, öğrenci çalışma ve öğretmen kılavuz kitaplarının yapılandırmacı yaklaşıma göre niteliğine ve saptanan sorunlara yönelik görüşleri. Yayımlanmamış Yüksek Lisans Tezi, Dokuz Eylül Üniversitesi Eğitim Bilimleri Enstitüsü, İzmir.

Kırcı, I. (2011). Illköğretim ikinci kademe Türkçe dersi ders kitapları, öğrenci çalışma kitapları ve öğretmen kılavuz kitaplarının çoklu zekâ kuramına uygunluk durumları. Yayımlanmamış Yüksek Lisans Tezi, Karadeniz Teknik Üniversitesi Eğitim Bilimleri Enstitüsü, Trabzon.

Küçükahmet, L. (2011). Eğitim programlarında ders kitabının yeri, Küçükahmet, L.(Ed.). Konu alanı ders kitabı inceleme içinde (ss.2-16) Ankara: Nobel Yayın Dağıtım.

Özatalay, H. (2007). Ilköğretim 1.kademe Türkçe öğretim programında öğrencilere kazandırılması hedeflenen temel becerilerin ders kitaplarında kullanılmasına ilişkin durum çalışması. Yayımlanmamış Doktora Tezi, Marmara Üniversitesi Eğitim Bilimleri Enstitüsü, İstanbul.

Sert, F. (2012). Illköğretim 7.sınıf Türkçe dersi öğretmen kılavuz kitabının yapılandırmacı öğrenme anlayışına göre incelenmesi. Yayımlanmamış Yüksek Lisans Tezi, Fırat Üniversitesi Eğitim Bilimleri Enstitüsü, Elazığ.

Şahin, A. (2008). Illköğretim birinci sınıf Türkçe ders kitabı, öğrenci çalışma kitabı ve öğretmen kılavuz kitabının öğretmen görüşlerine dayalı olarak değerlendirilmesi. Ahi Evran Üniversitesi Kırşehir Eğitim Fakültesi Dergisi, 9(3), 133-146.

Şahin, A. (2010). ilköğretim ikinci ve üçüncü sınıf Türkçe ders kitabı, öğrenci çalışma kitabı ve öğretmen kılavuz kitabının öğretmen görüşlerine dayalı olarak değerlendirilmesi. Milli Eğitim Dergisi, 185, 48-65.

Şimşek, N. (2004). Yapılandırmacı öğrenme ve öğretime eleştirel bir yaklaşım. Eğitim Bilimleri ve Uygulama, 3, (5), 115-139.

URL-1. Milli Eğitim Bakanlığı İlköğretim Türkçe Dersi (1.2.3.4.5.6.7.8.sınıflar) Taslak Öğretim Programı http://ttkb.meb.gov.tr/meb_iys_dosyalar/2015_06/12035807_Ikretimtrkedersitaslakretimprogram120615.pdf.(Erişim Tarihi:15.05.2016) 
İlköğretim 3.Sınıf Türkçe Ders Kitapları ve Öğretmen Kılavuz Kitabının Yapılandırmacı Öğrenme Yaklaşımına Uygunluk Düzeyi

Yapıcı, M. (2004). Illköğretim I.Kademe ders kitaplarının öğrenci düzeyine uygunluğu. Sosyal Bilimler Dergisi, 6(1), 121-131.

Yaşar, Ş. (1998). Yapısalcı kuram ve öğrenme-öğretme süreci. Anadolu Üniversitesi Eğitim Fakültesi Dergisi, 8(12), 68-75.

Yurdakul, B. (2004). Eğitimde davranışçıııtan yapılandırmacılığa geçiş için bilgi, gerçeklik ve öğrenme olgularının yeniden anlamlandırılması. Balıkesir Üniversitesi Sosyal Bilimler Enstitüsü Dergisi, 4(8), 109-120.

Yurdakul, B. (2008). Yapılandırmacı öğrenme yaklaşımının sosyal-bilişsel bağlamda bilgiyi oluşturmaya katkısı. Balıkesir Üniversitesi Sosyal Bilimler Enstitüsü Dergisi, 11(20), 39-67. 